\title{
Analisis Hambatan Fungsional Terhadap Adopsi Layanan Mobile Payment
}

\author{
Tintin Suhaeni* \\ Jurusan Administrasi Niaga, Politeknik Negeri Bandung, Indonesia
}

\begin{abstract}
:
Human needs are increasingly complex, demanding technological innovation to provide convenience and practicality in all respects, including the financial sector. Mobile payment is an innovative product that can answer those needs. With various facilities offered, users can conduct financial transactions without limited distance and time. However, behind these advantages, digital technology competition in Indonesia and non-cash transaction users in Indonesia are still low. Therefore, this study aims to analyze how much influence the functional barriers have on the adoption of mobile payment services in the city of Bandung by using the theory of functional barriers from the innovation resistance theory (ITR) model. A descriptive research method with a quantitative approach is used to process 150 data respondents who are not users of mobile payment services in the city of Bandung. Next, the data were analyzed using simple regression analysis. The results showed that functional barriers significantly influenced the adoption of mobile payment services in Bandung. The functional barrier of the innovation resistance theory (ITR) model in this study was able to explain the adoption of mobile payment services in Bandung by $15 \%$.
\end{abstract}

Keyword: adoption, functional barriers, mobile payment service

\begin{abstract}
Abstrak:
Kebutuhan manusia yang semakin komplek, menuntut inovasi teknologi untuk memberikan kemudahan dan kepraktisan dalam segala hal, termasuk sektor keuangan. Mobile payment menjadi produk inovatif yang dapat menjawab kebutuhan tersebut. Dengan berbagai kemudahan yang ditawarkan, pengguna dapat melakukan transaksi keuangan tanpa terbatas jarak dan waktu. Namun, dibalik keunggulan tersebut, kompetisi teknologi digital di Indonesia dan pengguna transaksi non-tunai di Indonesia masih rendah. Oleh karena itu, penelitian ini bertujuan untuk menganalisis seberapa besar pengaruh hambatan fungsional terhadap adopsi layanan mobile payment di Kota Bandung dengan menggunakan teori hambatan fungsional dari model innovation resistance theory (ITR). Metode penelitian deskriptif dengan pendekatan kuantitatif digunakan untuk mengolah 150 data responden yang bukan merupakan pengguna layanan mobile payment di Kota Bandung. Selanjutnya, data dianalisis dengan menggunakan analisis regresi sederhana. Hasil penelitian menunjukkan bahwa hambatan fungsional berpengaruh secara signifikan terhadap adopsi layanan mobile payment di Kota Bandung. Hambatan fungsional model innovation resistance theory (ITR) pada penelitian ini mampu menjelaskan adopsi layanan mobile payment di Kota Bandung sebesar $15 \%$.
\end{abstract}

Kata Kunci: adopsi, hambatan fungsional, layanan mobile payment 


\section{Pendahuluan}

Perkembangan teknologi baru mendorong munculnya inovasi yang berdampak pada seluruh aspek kehidupan manusia. Inovasi teknologi terjadi di berbagai sektor industri, termasuk industri keuangan. Inovasi teknologi berdampak pada perilaku konsumen, mendorong mereka menuju masyarakat yang sangat bergantung pada ponsel pintar (smartphone) (Shin, Hong, \& Dey, 2012). Sehingga, seiring dengan perkembangan teknologi yang semakin meningkat, lembaga keuangan dan konsumen dapat mengambil keuntungan dari efisiensi yang diperoleh dari teknologi itu sendiri (Riquelme \& Rios, 2010). Ponsel pintar (smartphone) menjadi perangkat yang menghubungkan konsumen dengan berbagai macam layanan keuangan. Di Indonesia sendiri, pertumbuhan pengguna smartphone terus meningkat dari tahun ke tahun. Padaakhir tahun 2019 diperkirakan jumlah pengguna smartphone di Indonesia akan mencapai 76.64 juta pengguna dan jumlah ini diperkirakan akan terus meningkat dari tahun ke tahun hingga tahun 2022 (Statista, 2019).

Tingginya pengguna smartphone menciptakan peluang bagi perkembangan mobile payment sebagai penyedia layanan keuangan non-tunai. Mobile payment merupakan sebuah inovasi teknologi di sektor keuangan yang menyediakan fitur pembayaran non-tunai untuk kebutuhan jual-beli, membayar tagihan, membeli pulsa, transfer dana, membayar layanan transportasi online, hingga melakukan berbagai jenis transaksi lainnya. Mobile payment memudahkan penggunanya untuk melakukan transaksi dimanapun dan kapanpun tanpa terbatas ruang dan waktu, sekaligus menjadi salah satu alternatif untuk merangkul lapisan masyarakat yang belum memiliki akses terhadap layanan sistem pembayaran dan keuangan (belum memiliki rekening di bank). Akan tetapi, dibalik berbagai kelebihan yang ditawarkan inovasi teknologi, beberapa perusahaan menghadapi kegagalan inovasi (Kleijnen, Lee, \& Wetzels, 2009) yang dapat dikaitkan dengan perilaku resistensi konsumen, sehingga akan muncul tantangan dan hambatan terhadap penerimaan inovasi yang dapat diperhitungkan oleh pasar mobile payment (Dotzauer \& Haiss , 2017). Resistensi inovasi terhadap suatu produk atau layanan tidak hanya terjadi dikarenakan inovasi tersebut gagal diterapkan, melainkan juga terjadi pada inovasi yang berhasil di adopsi (Ram, A Model of Innovation Resistance, 1987). Sehingga penting untuk mempelajari dan mengetahui hambatan untuk mencegah resistensi konsumen sebelum adopsi terjadi.

Berdasarkan laporan Digital Competitiveness Ranking tahun 2018 yang menilai tingkat kompetisi penggunaan teknologi digital di berbagai negara, menunjukkan bahwa Indonesia menempati urutan ke 14 sebagai negara dengan tingkat penggunaan teknologi digital terendah dibandingkan negara-negara di Asia-Pasifik (IMD, 2018). Hal ini menggambarkan bahwa kesadaran terhadap kompetisi teknologi digital di Indonesia masih rendah. Selain itu, 73 persen penduduk Indonesia masih menyukai transaksi tunai. Angka ini lebih tinggi dibandingkan rata-rata penduduk Asia yang pada umumnya mencapai 57 persen, yang menggambarkan bahwa masih sedikitnya masyarakat Indonesia yang beralih ke pembayaran non-tunai termasuk mobile payment (PayPal, 2018). Sehingga perlu dipelajari dan diketahui hal-hal apa saja yang menjadi hambatan masyarakat dalam mengadopsi inovasi teknologi mobile payment.

Kebutuhan untuk memahami alasan mengapa konsumen menolak inovasi daripada mengadopsinya sangat diperlukan mengingat berkembangnya jumlah pengguna smartphone yang akan berpotensi meningkatkan pengguna mobile payment dan rendahnya kompetisi penggunaan teknologi digital di Indonesia. Hal ini dikarenakan konsumen menjadi penyebab yang signifikan terhadap kegagalan pasar dalam sebuah inovasi (Cheng, Lee, \& Lee, 2014). Ketika strategi pemasaran hanya berfokus pada manfaat mobile payment seperti hanya memperhatikan faktor kenyamanan akan gagal meyakinkan konsumen yang peduli dengan masalah keamanan. Oleh karena itu, penting bagi pelaku bisnis untuk mengetahui hambatan dan alasan yang menghalangi konsumen untuk mengadopsi sebuah produk atau layanan inovasi (Claudy, 2011), (Kleijnen, Lee, \& Wetzels, 2009).

Pendekatan secara teoritikal menggunakan model resistensi inovasi yang dikembangkan oleh (Ram \& Sheth, Consumer Resistance to Innovations: The Marketing Problem and Its Solutions, 1989), meskipun sudah cukup tua, model ini masih relevan dalam penelitian saat ini karena telah diterapkan dalam beberapa penelitian mengenai inovasi teknologi seperti mobile banking dan mobile commerce (Dotzauer \& Haiss , 2017). Model IRT merupakan model yang paling banyak digunakan dalam penelitian resistensi inovasi dan terus dimodifikasi dan diuji dalam konteks yang 
berbeda (Laukkanen \& Kiviniemi, The role of information in mobile banking resistance, 2010). Sehingga model penelitian ini cocok untuk diterapkan dalam konteks mobile payment. Hambatan fungsional dalam model IRT merupakan fokus dalam penelitian ini karena hambatan fungsional berkaitan secara langsung dengan inovasi teknologi.

Penelitian ini bertujuan untuk menganalisis seberapa besar pengaruh hambatan fungsional terhadap adopsi layanan mobile payment di Kota Bandung. Mobile payment memiliki peluang untuk berkembang di Kota Bandung, karena Kota Bandung merupakan bagian dari provinsi Jawa Barat yang tingkat pengguna internetnya tertinggi di Indonesia yaitu sebesar 16.7\% dari total pengguna internet di Indonesia, sehingga menarik untuk diobservasi (Asosiasi Penyelenggara Jasa Internet Indonesia (APJII), 2018). Temuan dari penelitian ini diharapkan dapat berkontribusi di bidang keilmuan dengan menyediakan strategi dan rekomendasi praktis bagi penyedia layanan mobile payment untuk meningkatkan adopsi layanan mobile payment. Seiring dengan semakin berkembangnya mobile payment di Indonesia, hambatan-hambatan yang menyebakan resistensi dalam adopsi layanan teknologi adalah informasi penting untuk meningkatkan laju adopsi (Moorthy, et al., 2017). Berdasarkan fenomena-fenomena tersebut, judul "Analisis Hambatan Fungsional Terhadap Adopsi Layanan Mobile Payment", menarik untuk diteliti.

\section{Tinjauan Pustaka}

\subsection{Hambatan Fungsional Model Innovation Resistance Theory (IRT)}

Model yang diterapkan dalam penelitian ini adalah Innovation Resistance Theory (IRT) yang dikembangkan oleh Ram dan Sheth (Ram \& Sheth, Consumer Resistance to Innovations: The Marketing Problem and Its Solutions, 1989). Meskipun sudah cukup tua, model ini masih relevan dalam penelitian saat ini karena telah diterapkan dalam beberapa penelitian mengenai inovasi teknologi seperti mobile banking dan mobile commerce (Dotzauer \& Haiss , 2017). Model IRT merupakan model yang paling banyak digunakan dalam penelitian resistensi inovasi dan terus dimodifikasi dan diuji dalam konteks yang berbeda (Laukkanen \& Kiviniemi, The role of information in mobile banking resistance, 2010). Resistensi yang dilakukan oleh konsumen terhadap suatu inovasi dikarenakan inovasi tersebut berpotensi menimbulkan perubahan status quo atau karena bertentangan dengan kepercayaan konsumen ( Ram \& Sheth, Consumer Resistance to Innovations: The Marketing Problem and Its Solutions, 1989). Penting bagi pelaku usaha untuk mengidentifikasi sumber-sumber resistensi terhadap inovasi ( Laukkanen \& Kiviniemi, The role of information in mobile banking resistance, 2010). Hal ini dikarenakan, dengan mengetahui dan memahami resistensi terhadap inovasi maka akan diketahui alasan-alasan yang memperlambat proses adopsi inovasi itu sendiri. Kebutuhan untuk mempelajari resistensi inovasi dikarenakan tingkat kegagalan produk baru yang sangat tinggi dihadapi oleh sebagian besar bisnis (Moorthy, et al., 2017). Namun, resistensi konsumen terhadap suatu inovasi tidak hanya terjadi dikarenakan inovasi tersbut gagal diterapkan, melainkan juga terjadi pada inovasi yang berhasil di adopsi (Ram, A Model of Innovation Resistance, 1987). Oleh karena itu, model IRT dikembangkan untuk menjelaskan alasan mengapa konsumen menolak inovasi, sehingga resistensi dapat diatasi sebelum adopsi berhasil dilakukan. Berdasarkan teori tersebut Ram dan Sheth ( Ram \& Sheth, Consumer Resistance to Innovations: The Marketing Problem and Its Solutions, 1989) menentukan dua hambatan dalam adopsi. Hambatan fungsional dan psikologi. Dalam penelitian ini, Hambatan fungsional dalam model IRT menjadi fokus penelitian, karena hambatan fungsional berkaitan secara langsung dengan inovasi teknologi.

Hambatan fungsional merupakan hambatan yang terkait langsung dengan inovasi itu sendiri ( Ram \& Sheth, Consumer Resistance to Innovations: The Marketing Problem and Its Solutions, 1989). Hambatan fungsional terdiri dari tiga aspek hambatan sebagai berikut:

1. Hambatan Penggunaan (Usage Barrier)

Hambatan penggunaan atau usage barrier mengacu pada kegunaan fungsional suatu inovasi yang mencakup dua aspek. Aspek pertama mengenai ukuran apakah produk atau layanan baru itu mudah atau sulit untuk digunakan, dan aspek kedua mengacu pada tingkat perubahan yang diperlukan konsumen saat menggunakan produk inovasi yang sebagian besar bertentangan dengan 
kebiasaan mereka (Laukkanen, Consumer adoption versus rejection decisions in seemingly similar service innovations: The case of the Internet and mobile banking, 2016).

2. Hambatan Nilai (Value Barrier)

Hambatan nilai atau value barrier merupakan resistensi yang timbul terhadap penggunaan produk atau layanan inovasi yang tidak memenuhi persepsi pengguna untuk memberikan nilai tambah dengan memanfaatkan inovasi dibandingkan dengan produk atau layanan alternatif lainnya (Rammile \& Nel, 2012). Hambatan nilai didasarkan pada nilai sebuah inovasi. Jika inovasi menwarkan nilai kinerja ke harga yang kuat dibandingkan dengan produk atau layanan alternative, tidak ada alasan bagi konsumen untuk berubah ( Ram \& Sheth, Consumer Resistance to Innovations: The Marketing Problem and Its Solutions, 1989).

\section{Hambatan Risiko (Risk Barrier)}

Konsumen yang sadar akan risiko cenderung akan menolak sebuah inovasi. Hambatan risiko merupakan ketidakpastian tentang kemungkinan negatif dari penggunaan produk atau layanan tertentu (Marett, Pearson, Pearson, \& Bergiel, 2014). Hambatan risiko atau risk barrier terdiri dari empat jenis risiko yaitu risiko fisik, risiko ekonomi, risikio fungsional, dan risiko sosial. Risiko fisik menggambarkan bahwa suatu inovasi dapat membahayakan seseorang, dalam segi inovasi teknologi risiko fisik berisi kekhawatiran tentang privasi dan informasi pribadi ( Chemingui \& lallouna, 2013). Risiko ekonomi berhubungan dengan harga yang dibayarkan untuk produk atau layanan baru yang meningkat ketika harganya tinggi ( Ram \& Sheth, Consumer Resistance to Innovations: The Marketing Problem and Its Solutions, 1989). Selanjutnya risiko fungsional yang mengacu pada fungsi inovasi yang menimbulkan ketakutan karena produk atau layanan relatif baru sehingga tidak berfungsi dengan baik ( Ram \& Sheth, Consumer Resistance to Innovations: The Marketing Problem and Its Solutions, 1989). Risiko sosial menggambarkan rasa takut dihakimi orang lain ketika memanfaatkan produk atau layanan baru ( Ram \& Sheth, Consumer Resistance to Innovations: The Marketing Problem and Its Solutions, 1989), namun risiko sosial ditemukan kurang relevan dalam konteks teknologi (Kleijnen, Lee, \& Wetzels, 2009).

\subsection{Adopsi}

Niat adopsi merupakan konsekuensi dari penjumlahan variabel yang berujung pada niat yang menunjukkan bahwa konsumen bersedia melakukan tindakan tertentu (Joubert \& Belle, 2013). Sebuah studi empiris yang dilakukan oleh Laukkanen dan Kiviniemi menyelidiki bagaimana hambatan teori inovasi mobile banking di Finlandia berpengaruh terhadap intensi adopsi mobile banking (Laukkanen, Consumer adoption versus rejection decisions in seemingly similar service innovations: The case of the Internet and mobile banking, 2016). Temuan studi di masa lalu konsisten dengan hipotesis penelitian dimana user barrier, value barrie, dan risk barrier mempengaruhi intensi adopsi sebuah produk atau layanan inovasi. Oleh karena itu, penting untuk mempelajari bagaimana individu bersedia untuk mencoba produk atau layanan baru yang memiliki efek pada persepsi konsumen terhadap layanan dan kesiapan adopsi mereka. Mengetahui hambatan (barrier) yang mencegah konsumen dari mengadopsi inovasi sangat penting. Hambatan dalam adopsi akan memengaruhi pemasaran inovasi karena mengatasi hambatan untuk mengurangi resistensi memerlukan strategi yang berbeda daripada meningkatkan adopsi inovasi (Claudy, 2011), (Kleijnen, Lee, \& Wetzels, 2009).

\subsection{Mobile Payment}

Mobile payment merupakan suatu pembayaran dengan menggunakan ponsel untuk melaksanakan dan mengonfirmasi pembayaran dan dapat dilakukan di berbagai lokasi (Untoro \& Dewi, 2013). Mobile payment dapat meningkatkan efektivitas dan efisiensi waktu, dengan menawarkan kepraktisan dan kemudahan dalam bertransaksi karena pengguna tidak perlu mengantri lama untuk melakukan pembayaran sehingga transaksi dapat dilakukan lebih efektif dan efisien. Di Indonesia terdapat tiga jenis mobile payment berdasarkan jenis perusahaan penyedia. Perusahaan teknologi finansial atau fintech yang mengeluarkan produk Gopay, OVO, Dana, DokuWallet, dan lainnya. Bank dengan produk BCA Sakuku, Mandiri Syariah Mobile, dan lainnya. Perusahaan operator dengan produk XL Tunai, T-Cash, dan produk lainnya. 


\section{Model Penelitian}

Model penelitian ini menghubungkan variabel hambatan fungsional dari model Innovation Resistance Theory (IRT) dengan dimensi terhadap adopsi layanan mobile payment. Model yang paling banyak digunakan dalam penelitian resistensi inovasi dan terus dimodifikasi serta diuji dalam konteks yang berbeda adalah model innovation resistance theory (ITR) yang dikemukakan oleh Ram dan Sheth (1989). Teori ini menyatakan bahwa terdapat 2 hambatan (barrier) dalam adopsi, salah satunya adalah hambatan fungsional yang terdiri dari hambatan penggunaan (usage barrier), hambatan nilai (value barrier), dan hambatan risiko (risk barrier). Mengatasi hambatan untuk mengurangi resistensi konsumen memerlukan strategi yang berbeda daripada meningkatkan adopsi inovasi (Claudy, 2011), (Kleijnen, Lee, \& Wetzels, 2009). Sehingga hipotesis yang digunakan pada penelitian ini adalah sebagai berikut:

H0: Tidak terdapat pengaruh hambatan fungsional terhadap adopsi layanan mobile payment

H1: Terdapat pengaruh hambatan fungsional terhadap adopsi layanan mobile payment

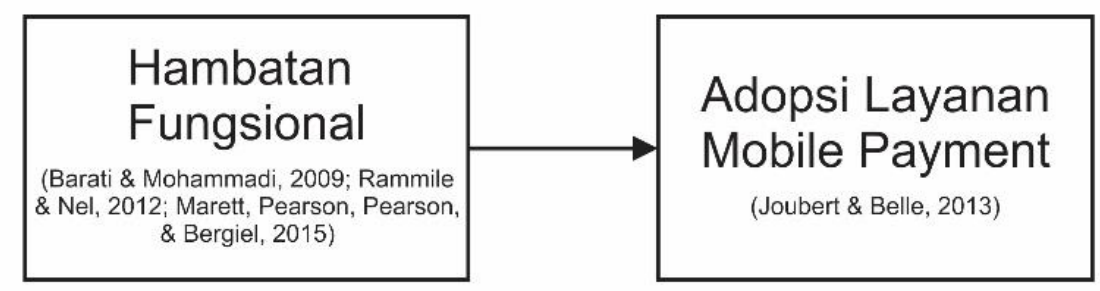

Gambar 1. Model Penelitian

\section{Metode Penelitian}

Penelitian ini menggunakan metode analisis deskriptif dengan pendekatan kuantitatif.

\subsection{Pengumpulan Data}

Data primer dalam penelitian diperoleh dari hasil penyebaran kuesioner dengan metode purposive sampling kepada 150 responden yang tidak menggunakan layanan mobile payment di Kota Bandung. Item-item pertanyaan kuesioner variabel hambatan fungsional diadopsi dari penelitian Barati dan Mohammadi; Rammile dan Nel; serta Marett, Pearson, Pearson, dan Bergiel (Barati \& Mohammadi, 2009), (Rammile \& Nel, 2012), (Marett, Pearson, Pearson, \& Bergiel, 2014). Sementara variabel adopsi layanan diadopsi dari penelitian Joubert dan Belle (Joubert \& Belle, 2013), yang kemudian disesuaikan dengan konteks teknologi mobile payment. Item pertanyaan menggunakan skala Likert dengan skala 1 sampai 5 untuk mengukur sikap setuju atau tidak setuju responden terhadap butir pertanyaan.

\subsection{Analisis Data}

Data yang terpercaya menjadi hal terpenting dalam sebuah penelitian, sehingga uji validitas dan uji reliabilitas penting dilakukan untuk mengetahui kelayakan dan ketepatan item-item instrumen penelitian Instrumen penelitian dikatakan sudah tepat dan valid, apabila nilai $\mathrm{r}_{\text {hitung }}$ lebih besar dari $\mathrm{r}_{\text {tabel. }}$ Teknik pengukuran reliabilitas salah satunya menggunakan teknik alpha cronbach koefisien reliabilitas $>0,6$. Selanjutnya dilakukan uji asumsi klasik. Uji asumsi klasik dalam penelitian ini terdiri dari uji normalitas menggunakan uji Kolmogorov-Smirnov, uji linearitas, dan uji heteroskedastisitas menggunakan uji glejser. Analisis deskriptif deskriptif memperlihatkan nilai minimum, nilai maksimum, rata-rata (mean), dan standar deviasi variabel hambatan fungsional dan variabel adopsi layanan. Kemudian nilai hasil analisis deskriptif diinterpretasikan kedalam interval yang terdiri dari kriteria, rendah sekali (1.00-1.80); rendah (1.81-2.60); cukup (2.61-3.40); tinggi (3.41-4.20); dan sangat tinggi (4.21-5.00). Selanjutnya, analisis regresi linier sederhana untuk mengukur perubahan variabel dependen berdasarkan perubahan-perubahan variabel independen. Setelah itu dilakukan uji hipotesis untuk pengambilan keputusan. Uji hipotesis dalam penelitian ini menggunakan uji $\mathrm{F}$ dan uji t. 


\section{Hasil Penelitian}

\subsection{Demografis Responden}

Tabel 1 Demografis responden

\begin{tabular}{|c|c|c|}
\hline \multirow{2}{*}{$\begin{array}{c}\text { Jenis } \\
\text { Kelamin }\end{array}$} & Perempuan & $66 \%$ \\
\hline & Laki-laki & $34 \%$ \\
\hline \multirow{4}{*}{ Usia } & 20-29 Tahun & $49 \%$ \\
\hline & 30-39 Tahun & $23 \%$ \\
\hline & 40-49 Tahun & $2 \%$ \\
\hline & $>50$ Tahun & $2 \%$ \\
\hline \multirow{6}{*}{ Pekerjaan } & Karyawan Swasta & $27 \%$ \\
\hline & Pegawai Negeri Sipil & $18 \%$ \\
\hline & Wiraswasta & $5 \%$ \\
\hline & Pelajar/Mahasiswa & $24 \%$ \\
\hline & Ibu Rumah Tangga & $23 \%$ \\
\hline & Lainnya & $3 \%$ \\
\hline \multirow{6}{*}{ Pendidikan } & S3 & $4 \%$ \\
\hline & S2 & $14 \%$ \\
\hline & S1 & $17 \%$ \\
\hline & D1/D2/D3 & $5 \%$ \\
\hline & SMA & $50 \%$ \\
\hline & SMP & $10 \%$ \\
\hline \multirow{4}{*}{$\begin{array}{l}\text { Pendapatan } \\
\text { (Sebulan) }\end{array}$} & $<$ Rp2.500.000 & $53 \%$ \\
\hline & $\begin{array}{l}\text { Rp2.500.000- } \\
\text { Rp5.000.000 }\end{array}$ & $27 \%$ \\
\hline & $\begin{array}{l}\text { Rp5.000-000- } \\
\text { Rp7.500.000 }\end{array}$ & $6 \%$ \\
\hline & $>\mathrm{Rp} 7.500 .000$ & $14 \%$ \\
\hline
\end{tabular}

5.2 Uji Validitas, Reliabilitas, dan Asumsi Klasik

Berdasarkan tabel 2, dapat diketahui item pertanyaan valid sebagai instrumen penelitian karena nilai $\mathrm{r}_{\text {hitung }}$ lebih besar dari $\mathrm{r}_{\text {tabel. }}$ Tabel 3 menunjukkan hasil uji reliabilitas sudah reliabel karena telah memenuhi kriteria nilai cronbach's alpha $>0.6$.

Berdasarkan tabel 4 diketahui bahwa nilai Asymp. Sig. adalah 0.100. Hasil uji normalitas yang dihitung menunjukkan bahwa variabel terdistribusi secara normal karena nilai Asymp. Sig. lebih besar dari 0.05 . Berdasarkan tabel 5 dapat diketahui bahwa hubungan variabel hambatan fungsional dan adopsi layanan mobile wallet memenuhi asumsi linearitas karena nilai sig. linearity kurang dari 0.05. Uji heteroskedastisitas menggunakan uji glejser. Tabel 6 menunjukkan nilai signifikansi (Sig.) variabel $>0.05$. Maka dapat dikatakan bahwa data tidak mengalami gejala heteroskedastisitas dalam model regresi.

Tabel 2 Uji Validitas

\begin{tabular}{|c|c|c|c|}
\hline $\begin{array}{c}\text { Item } \\
\text { Pertanyaan }\end{array}$ & rhitung $_{\text {HB1 }}$ & $\mathbf{r}_{\text {tabel }}$ & Keterangan \\
\hline HB2 & 0.726 & 0.1339 & Valid \\
\hline HB3 & 0.766 & 0.1339 & Valid \\
\hline HB4 & 0.712 & 0.1339 & Valid \\
\hline HB5 & 0.677 & 0.1339 & Valid \\
\hline HB6 & 0.658 & 0.1339 & Valid \\
\hline HB7 & 0.699 & 0.1339 & Valid \\
\hline
\end{tabular}




\begin{tabular}{|c|l|l|l|}
\hline HB8 & 0.660 & 0.1339 & Valid \\
\hline HB9 & 0.594 & 0.1339 & Valid \\
\hline HB10 & 0.664 & 0.1339 & Valid \\
\hline HB11 & 0.663 & 0.1339 & Valid \\
\hline HB12 & 0.646 & 0.1339 & Valid \\
\hline HB13 & 0.497 & 0.1339 & Valid \\
\hline HB14 & 0.576 & 0.1339 & Valid \\
\hline AI1 & 0.885 & 0.1339 & Valid \\
\hline AI2 & 0.901 & 0.1339 & Valid \\
\hline AI3 & 0.869 & 0.1339 & Valid \\
\hline AI4 & 0.857 & 0.1339 & Valid \\
\hline AI5 & 0.829 & 0.1339 & Valid \\
\hline AI6 & 0.824 & 0.1339 & Valid \\
\hline
\end{tabular}

Tabel 3 Uji Reliabilitas

\begin{tabular}{|l|c|c|}
\hline Variabel & Cronbach's alpha & Jumlah item \\
\hline Hambatan Fungsional & 0.895 & 14 \\
\hline Adopsi & 0.930 & 6 \\
\hline
\end{tabular}

Tabel 4 Uji Normalitas Kolmogorov-Smirnov

\begin{tabular}{|l|l|l|}
\hline \multicolumn{2}{|l|}{} & \multicolumn{1}{c|}{$\begin{array}{c}\text { Unstandardized } \\
\text { Residual }\end{array}$} \\
\hline $\mathrm{N}$ & Mean & 150 \\
\hline \multirow{2}{*}{ Normal Parameters ${ }^{\mathrm{a}, \mathrm{b}}$} & Std. Deviation & .0000000 \\
\hline \multirow{3}{*}{ Most Extreme Differences } & Absolute & 4.25028609 \\
\cline { 2 - 3 } & Positive & .067 \\
\cline { 2 - 3 } & Negative & .043 \\
\hline Test Statistic & -.067 \\
\hline Asymp. Sig. (2-tailed) & .067 \\
\hline
\end{tabular}

Tabel 5 Uji Linieritas

\begin{tabular}{|c|c|c|c|c|c|c|c|}
\hline & $\begin{array}{c}\text { Sum of } \\
\text { Squares }\end{array}$ & $\mathrm{df}$ & $\begin{array}{l}\text { Mean } \\
\text { Square }\end{array}$ & $\mathrm{F}$ & Sig. \\
\hline \multirow{5}{*}{$\begin{array}{l}\mathrm{AI} * \\
\mathrm{HB}\end{array}$} & \multirow{3}{*}{$\begin{array}{l}\text { Between } \\
\text { Groups }\end{array}$} & (Combined) & 1591.653 & 41 & 38.821 & 2.659 & .000 \\
\hline & & Linearity & 476.465 & 1 & 476.465 & 32.641 & .000 \\
\hline & & $\begin{array}{c}\text { Deviation from } \\
\text { Linearity }\end{array}$ & 1115.188 & 40 & 27.880 & 1.910 & .005 \\
\hline & \multicolumn{2}{|c|}{ Within Groups } & 1576.487 & 108 & 14.597 & & \\
\hline & \multicolumn{2}{|c|}{ Total } & 3168.140 & 149 & & & \\
\hline
\end{tabular}

Tabel 6 Uji Heteroskedastisitas

\begin{tabular}{|c|c|}
\hline Variabel & Koefisien Sig. \\
\hline Hambatan Fungsional & 0.481 \\
\hline
\end{tabular}




\subsection{Analisis Deskriptif}

Berdasarkan tabel 7, dimensi usage barrier dengan nilai rata-rata 2.37, menginterpretasikan bahwa resistensi terhadap ketidaknyamanan dan kompleksitas dalam menggunakan layanan mobile payment tergolong rendah. Sementara value barrier dengan rata-rata nilai 2.63 menggambarkan bahwa resistensi terhadap penggunaan mobile payment yang tidak memenuhi persepsi pengguna untuk memberikan nilai tambah dibandingkan dengan layanan alternatif lainnya cukup tinggi. Adapun risk barrier dengan nilai mean 3.55 menginterpretasikan resistensi terhadap ketidakpastian akan kemungkinan negatif dari penggunaan mobile payment tergolong tinggi. Secara keseluruhan dapat diketahui resistensi hambatan fungsional untuk mengadopsi mobile payment di Kota Bandung tergolong cukup tinggi, dengan nilai rata-rata 2.85. Nilai standar deviasi hambatan fungsional sebesar $37 \%$ menunjukkan tingkat variasi jawaban responden yang beragam.

Tabel 8 menunjukkan nilai rata-rata adopsi sebesar 3.69. Hal ini menginterpretasikan bahwa niat responden untuk mengadopsi layanan mobile payment di Kota Bandung tergolong tinggi. Standar deviasi adopsi menunjukkan tingkat variasi jawaban responden yang cukup beragam dengan nilai $24 \%$.

Tabel 7 Analisis Deskriptif Variabel Hambatan Fungsional

\begin{tabular}{|l|c|c|}
\hline & Mean & Std. Deviation \\
\hline Usage Barrier & 2.37 & 0.99 \\
\hline Value Barrier & 2.63 & 1.13 \\
\hline Risk Barrier & 3.55 & 1.08 \\
\hline Hambatan Fungsional & 2.85 & 1.06 \\
\hline
\end{tabular}

Tabel 8 Analisis Deskriptif Variabel Adopsi

\begin{tabular}{|l|c|c|}
\hline & Mean & Std. Deviation \\
\hline Adopsi & 3.69 & 0.89 \\
\hline
\end{tabular}

\subsection{Regresi Linier Sederhana}

Tabel 9 dapat diketahui bahwa nilai konstanta (a) bernilai 29.545 dan nilai koefisien regresi sebesar -0.182. Ini berarti, setiap pengurangan satu angka hambatan fungsional dengan koefisien bernilai negatif, maka adopsi layanan mobile payment akan mengalami peningkatan sebesar 0.182. Berdasarkan tabel 10 dapat diketahui nilai koefisien determinasi atau R square sebesar 0.150 yang artinya $15 \%$ hambatan fungsional dapat memengaruhi adopsi layanan mobile payment di Kota Bandung sebesar 15\%, sedangkan sisanya $85 \%$ dipengaruhi oleh faktor lain yang tidak dijelaskan dalam penelitian ini.

Tabel 9 Analisis Regresi Linier Sederhana

\begin{tabular}{|c|c|c|c|c|c|c|}
\hline \multirow{2}{*}{ Model } & \multicolumn{2}{|c|}{$\begin{array}{c}\text { Unstandardized } \\
\text { Coefficients }\end{array}$} & \multirow{2}{*}{$\begin{array}{c}\text { Standardized } \\
\text { Coefficients }\end{array}$} & \multirow{2}{*}{$\mathrm{t}$} & \multirow{2}{*}{ Sig. } \\
\cline { 3 - 7 } & B & Std. Error & Beta & & \\
\hline \multirow{2}{*}{1} & (Constant) & 29.545 & 1.480 & & 19.956 & .000 \\
\cline { 2 - 7 } & HB & -.182 & .036 & -.388 & -5.118 & .000 \\
\hline \multicolumn{7}{|r|}{} \\
\hline
\end{tabular}

Tabel 10 Koefisien Determinasi

\begin{tabular}{|l|c|c|c|c|}
\hline Model & $\mathrm{R}$ & $\begin{array}{c}\mathrm{R} \\
\text { Square }\end{array}$ & $\begin{array}{c}\text { Adjusted R } \\
\text { Square }\end{array}$ & $\begin{array}{c}\text { Std. Error of } \\
\text { the Estimate }\end{array}$ \\
\hline 1 & $.388^{\mathrm{a}}$ & .150 & .145 & 4.26462 \\
\hline a. Predictors: (Constant), HB \\
b. Dependent Variable: AI \\
\hline
\end{tabular}




\subsection{Uji Hipotesis}

Tabel 11 menunjukkan nilai $F$ hitung sebesar 26.19, sementara nilai $F$ tabel dengan $\mathrm{df} 1=1$, dan df2=148 dengan tingkat signifikansi 0.05 adalah 3.91. Nilai $F$ hitung penelitian lebih besar dari $F$ tabel menunjukkan $\mathrm{H}_{0}$ ditolak dan $\mathrm{H}_{1}$ diterima, sehingga terdapat pengaruh yang signifikan antara hambatan fungsional terhadap adopsi layanan mobile payment.

Uji statistik t dapat diperoleh dari tabel 9, dimana thitung penelitian sebesar 19.956. Sementara nilai $t$ tabel dengan signifikansi 0.05 dan $\mathrm{df}=150$ adalah sebesar 1.97591. Tabel $\mathrm{t}$ hitung lebih besar dari t tabel, maka dapat disimpulkan bahwa $\mathrm{H}_{0}$ ditolak dan $\mathrm{H}_{1}$ diterima, yang juga menunjukkan bahwa terdapat pengaruh yang signifikan antara hambatan fungsional terhadap adopsi layanan mobile payment. Nilai probabilitas 0.000 pada tabel 9 yang lebih kecil dari 0.05 menggambarkan bahwa model regresi dapat digunakan untuk memprediksi adopsi layanan mobile payment di Kota Bandung.

\begin{tabular}{|c|c|c|c|c|c|c|}
\multicolumn{9}{|c|}{ Tabel 11 Uji F } \\
\hline \multicolumn{2}{|c|}{ Model } & $\begin{array}{c}\text { Sum of } \\
\text { Squares }\end{array}$ & df & Mean Square & F & Sig. \\
\hline \multirow{3}{*}{1} & Regression & 476.465 & 1 & 476.465 & 26.198 & $.000^{\mathrm{b}}$ \\
\cline { 2 - 7 } & Residual & 2691.675 & 148 & 18.187 & & \\
\cline { 2 - 8 } & Total & 3168.140 & 149 & & & \\
\hline
\end{tabular}

\section{Kesimpulan}

Berdasarkan hasil pengolahan dan analisis data dapat diketahui hambatan fungsional mobile payment di Kota Bandung tergolong cukup tinggi. Hambatan fungsional mobile payment diukur dari tiga dimensi hambatan fungsional, yaitu hambatan penggunaan, hambatan nilai, dan hambatan risiko. Dimensi hambatan penggunaan mempunyai nilai rata-rata terendah yang menunjukkan bahwa resistensi terhadap ketidaknyamanan dan kompleksitas dalam menggunakan layanan mobile payment tergolong rendah. Sementara hambatan risiko merupakan dimensi yang memiliki nilai ratarata tertinggi yang menginterpretasikan resistensi terhadap ketidakpastian akan kemungkinan negatif dari penggunaan mobile payment. Indikator dengan nilai rata-rata tertinggi pada dimensi hambatan risiko ditujukan oleh indikator ketakutan akan tersebarnya data privasi ketika menggunakan mobile payment. Sementara, indikator terendah terdapat pada indikator mobile payment lambat untuk digunakan yang termasuk ke dalam dimensi hambatan penggunaan mobile payment. Selain itu, niat untuk mengadopsi layanan mobile payment di Kota Bandung tergolong cukup tinggi, yang diukur oleh enam indikator penelitian. Indikator dengan nilai rata-rata tertinggi terdapat pada indikator niat adopsi layanan mobile payment untuk meningkatkan kenyamanan. Hal ini menginterpretasikan bahwa masyarakat di Kota Bandung cenderung memiliki niat untuk mengadopsi layanan mobile payment karena ingin meningkatkan kenyamanan ketika melakukan transaksi. Sementara indikator terendah terdapat pada indikator merekomendasikan mobile payment kepada keluarga dan kerabat. Penelitian ini menunjukkan adanya pengaruh yang signifikan antara hambatan fungsional terhadap adopsi penggunaan mobile payment di Kota Bandung. Besarnya pengaruh hambatan fungsional terhadap adopsi penggunaan mobile payment adalah sebesar $15 \%$, sedangkan sisanya $85 \%$ dipengaruhi oleh faktor lain yang tidak dijelaskan dalam penelitian ini.

\section{Daftar Pustaka}

Asosiasi Penyelenggara Jasa Internet Indonesia. (2018) Hasil Survei Penetrasi dan Perilaku Pengguna Internet Indonesia 2018. Jakarta: Asosiasi Penyelenggara Jasa Internet Indonesia (APJII).

Shin, C., Hong, J., \& Dey, A. K. (2012). Understanding and prediction of mobile application usage for smart phones. Proceedings of the 2012 ACM Conference on Ubiquitous Computing. Pennsylvania, 173-182.

Chemingui, H. \& lallouna, H. B. (2013). Resistance, motivations, trust and intention to use mobile financial services. International Journal of Bank Marketing, 31 (7).

Riquelme, H. E. \& Rios, R. E. (2010). The moderating effect of gender in the adoption of mobile banking. International Journal of Bank Marketing, 28 (5), 328-341. 
IMD. (2018). The IMD World Digital Competitiveness Ranking 2018. New York: IMD.

Joubert, J. \& Belle, J. V. (2013). The Role of Trust and Risk in Mobile Commerce Adoption within South Africa. International Journal of Business, Humanities and Technology, 3 (1), 27-38.

Dotzauer, K. \& Haiss, F. (2017). Barriers towards the adoption of mobile payment services: An empirical investigation of consumer resistance in the context of Germany. Tesis. Karlstad University.

Marett, K., Pearson, A. W., Pearson, R. A., \& Bergiel, E. B. (2014). Using mobile devices in a highrisk context: The role of risk and trust in an exploratory study in Afghanistan. Technology in Society, 41 (1).

Moorthy, K. (2017). Barriers of Mobile Commerce Adoption Intention: Perceptions of Generation X in Malaysia. Journal of Theoretical and Applied Electronic Commerce Research, 12 (2), $37-$ 53.

laudy, M. (2011). An Empirical Investigation of Consumer Resistance to Green Product Innovation. Disertasi. University College Dublin.

Kleijnen, M., Lee, N. \& Wetzels, M. (2009). An exploration of consumer resistance to innovation and its antecedents. Journal of Economic Psychology, 30 (3), 344-357.

Rammile, N. \& Nel, J. (2012). Understanding resistance to cell phone banking. African Journal of Business Management, 6 (1), 86-97.

PayPal. (2018). Digital Payments: Thinking beyond Transactions. Palo Alto: PayPal.

Untoro, R. A. T. \& Dewi, K. (2013). Pemetaan Produk dan Risiko Pembayaran Bergerak (Mobile Payment) dalam Sistem Pembayaran di Indonesia. Jakarta: Bank Indonesia.

Ram, S. \& Sheth, J. N. (1989). Consumer Resistance to Innovations: The Marketing Problem and Its Solutions. Journal of Consumer Marketing, 6 (2).

Ram, S. A Model of Innovation Resistance. Advances in Consumer Research, 14 (19), 208-212,

Barati, S. \& Mohammadi, S. (2009). An Efficient Model to Improve Customer. in Proceedings of the World Congress on Engineering and Computer Science. San Fransisco.

Cheng, S., Lee, S. \& Lee, K. (2014). User resistance of mobile banking in China: Focus on perceived risk. International Journal of Security and Its Applications, 8 (2), 167-172.

Statista. (2019) Number of smartphone users in Indonesia from 2011 to 2022 (in millions) *. [Online]. https://www.statista.com/statistics/266729/smartphone-users-in-indonesia/

Laukkanen, T. \& Kiviniemi, V. (2010). The role of information in mobile banking resistance. International Journal of Bank Marketing, 28 (5), 372-388.

Laukkanen, T. (2016). Consumer adoption versus rejection decisions in seemingly similar service innovations: The case of the Internet and mobile banking. Journal of Business Research, 69 (7), 2432-2439.

*Email korespondensi:

tintin.suhaeni@polban.ac.id 